\title{
What Can the US System of Financial Arbitration Learn from Overseas Jurisdictions? An Initial Responsive Empirical Exploration
}

\author{
Shahla F. Ali \\ July 4, 2012
}

\begin{abstract}
The United States largely relies on a system of arbitration to handle retail consumer financial disputes. This approach has undergone significant challenge in recent years particularly in light of recent abuses of consumer credit arbitration mechanisms.

This paper reports on the results of a non-randomized small-n survey which we label the "Financial Dispute Study" aimed at evaluating the relative effectiveness of two major approaches to financial dispute resolution - arbitration and ombuds services. Nearly a hundred survey questionnaires were distributed to financial dispute resolution practitioners throughout the world. A total of forty-eight arbitrators and ombuds people from East Asia, North America, Europe, the Middle East and Africa responded. In the Study participants were asked how practitioners viewed the level of satisfaction, settlement rate and perceived increase or decrease in the use of the given method of financial dispute resolution - whether arbitration or ombuds service. This paper analyzes the method-effect, meaning we focus on the effect of the selected method of financial dispute resolution (whether ombuds or arbitration) on settlement, satisfaction and increase or decrease in use. In doing so, the study evaluates the relative effectiveness of two major approaches a financial dispute resolution mechanism might adopt.

We find no statistically significant evidence that a given method, arbitration or the use of ombuds process has a large (or any) effect on the settlement rate, level of satisfaction and usage. To the contrary, arbitration and ombuds group point estimates are generally close to one another. Nevertheless, the data indicate slightly higher levels of settlement and overall increase in use in ombuds processes worldwide. These findings, combined with feedback from open ended interviews along with structural safeguards against repeat-player advantage integrated into the ombuds process ensuring that awards are rendered without prejudice to the claimant, suggest that merit may be found in exploring the potential applications and use of ombuds processes for the resolution of US consumer financial disputes. The paper concludes with some limited interpretation of the results.
\end{abstract}

\footnotetext{
- Assistant Professor, Faculty of Law, University of Hong Kong. B.A., Stanford University; J.D./PhD, Boalt Hall School of Law, Jurisprudence and Social Policy Program, University of California at Berkeley. The author wishes to thank the University of Hong Kong Research Committee for its kind support of this project. Special thanks also to Lee Epstein and Andrew D. Martin for their very helpful workshop on Conducting Empirical Legal Scholarship.
} 


\section{Introduction}

The United States largely relies on a system of arbitration to handle retail consumer financial disputes. This approach has undergone significant challenge in recent years particularly in light of recent abuses of consumer credit arbitration mechanisms. The global reach of the financial crisis calls for renewed investigation of how governments and self-regulatory organisations in major financial centres can effectively employ responsive dispute resolution mechanisms to address citizen complaints arising from financial dislocation. Such an examination is important not only to help us understand the dynamics of resolving complex consumer disputes in times of financial crisis, but also to prepare us to apply lessons learned to the design of more robust, fair and efficient centres for the prevention and resolution of future financial disputes.

\section{Survey}

In order to assess how arbitrators and ombudsmen view the benefits, challenges and suggestions for the improvement of both ombuds and arbitration processes, a survey was conducted between the Fall of 2011 and the Summer of 2012. Nearly a hundred survey questionnaires were distributed to practitioners throughout the world. A total of forty-eight arbitrators and ombuds people from East Asia, North America, Europe, the Middle East and Africa responded. The participants represented highly experienced practitioners, members of government regulatory ombuds services and private arbitration commissions. The majority of those surveyed (44 per cent) had worked for institutions involved in consumer financial dispute resolution for more than four years.

\section{Survey Design}

The survey used in this study contained a quantitative part asking for yes-no answers and numerical responses in the form of percentage estimates or evaluations according to four and five-point scales. 
The first part of the survey asked participants background information on their years of experience, region of practice and primary method of resolving consumer financial disputes (i.e. arbitration, ombuds process or multi-tier process including the use of negotiation and mediation). The second part examined participants' observations regarding what they see as the benefits, challenges and areas for improvement in the resolution of consumer financial disputes using either arbitration or ombuds methods of resolution.

\section{Sample Pool and Distribution}

The sample pool consisted of ombuds people, arbitrators, mediators and members of consumer financial regulatory bodies. The sample group was selected from contacts made with members of the ABA Section of Dispute Resolution, ADR Resources Group, the Association for International Arbitration, the Commercial and Industry Arbitration and Mediation Group, the Commercial Dispute Resolution Group, CPR Institute, International Arbitration Group, the Ombuds Group, Resolution Systems Institute and participants at the Asia Pacific Mediation Forum in 2011.

Close to a hundred surveys were distributed to arbitrators, ombuds people and dispute resolution practitioners and a total of forty-eight individuals responded. The questions were distributed at ADR conferences in East Asia, on-line through an webbased survey collection site, and in person with members of arbitration centres in Shenzhen, Hong Kong, Macau, the United States and Europe.

Figure 1: Survey Participants 


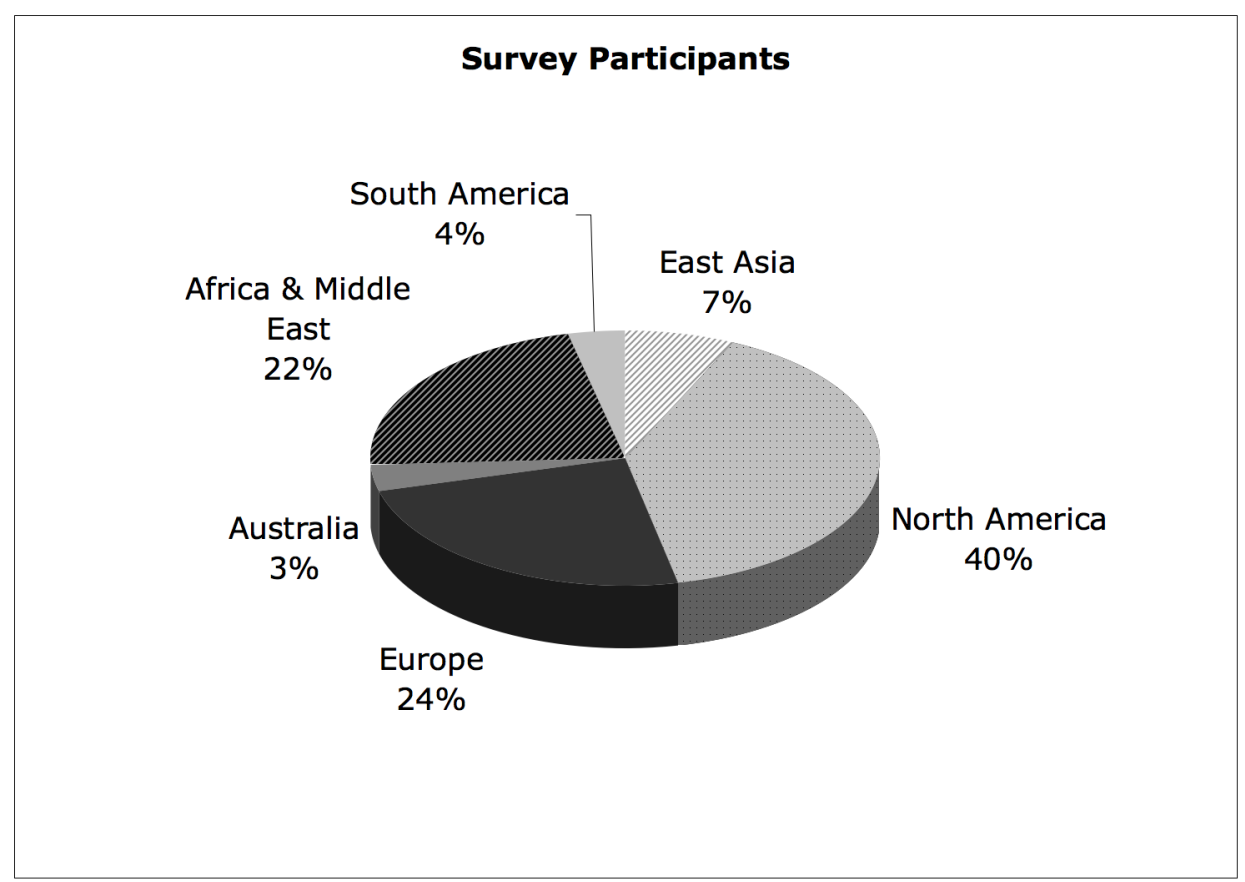

The summary of the findings are as follows: practitioners of consumer financial dispute resolution view ombuds processes as particularly useful in providing an independent and free review service for financial customers. At the same time the service also helps to identify areas of improvement and reform for banks. ${ }^{1}$ Perhaps as a result of such benefits, the use of ombuds processes has been increasing in recent years. The majority of respondents ( 89 per cent) indicated that they had in fact seen an increase in the use of ombuds processes in consumer financial dispute resolution in recent years. At the same time, practitioners acknowledged areas for continued improvement including the need for greater public education, ${ }^{2}$ oversight and quality assurance of ombuds processes. ${ }^{3}$

The summary of the findings in relation to the arbitration process are as follows: Arbitration practitioners viewed the benefits of arbitration services in consumer financial disputes as providing disputants with technical expertise "where the parties are not arguing over the law, but application of financial/accounting principles. ${ }^{4}$ In addition, respondents noted the 'speed, reduced expense and expertise of the neutral.' Among the challenges include 'proof issues, imbalance of power and

\footnotetext{
${ }^{1}$ Survey No. 1 (July 2011-March 2012).

${ }^{2}$ Survey No. 1 (July 2011-March 2012).

${ }^{3}$ Survey No. 4 (July 2011-March 2012).

${ }^{4}$ Survey No. 8 (July 2011-March 2012).
} 
information and lack of full discovery options/rights'. ${ }^{5}$ Concerns about such disparities were echoed by other participants who noted the prevalence of perceptions that 'large institutions have "repeat-user" advantage' ${ }^{6}$ Practitioners noted suggestions for improvement including the need for ' $[\mathrm{g}]$ ood program design [including] exit evaluations [and a] grievance process to allow parties to file complaints against neutrals who do not perform well'. In addition, 'a code of ethics for neutrals' was suggested along with 'anything that supports procedural due process'. ${ }^{7}$

\section{Background - Financial Dispute Resolution in the United States}

In the United States, several major programs exist for the resolution of consumer financial disputes. ${ }^{8}$ These include both private arbitration and courtannexed programs for credit card and bank loan complaints. Among the most prominent nationwide programs in the area of investment disputes is the Financial Industry Regulatory Authority ('FINRA'). What characterises most consumer dispute resolution programs in the United States is a common concern for efficiency and finality. However, such goals are increasingly being examined in the larger context of principles of equity and transparency as limited opportunities exist for court oversight and no general right of appeal exists on the part of the complainant to pursue claims in court (as in the ombuds model) if the complainant is not satisfied with the final award.

\section{The American Arbitration Association}

Among the more prominent alternative financial dispute resolution scheme, the American Arbitration Association ('AAA') provides a special set of rules for financial disputes: the AAA Arbitration Rules for Commercial Financial Disputes, which are applicable to all disputes relating to commercial financial arrangements,

\footnotetext{
${ }^{5}$ Survey No. 10 (July 2011-March 2012).

${ }^{6}$ Survey No. 14 (July 2011-March 2012).

${ }^{7}$ Survey No. 10 (July 2011-March 2012).

${ }^{8}$ For comparative elaboration, see: Ali, S., Consumer Financial Dispute Resolution in a Comparative Context: Principles, Systems and Practice, Cambridge University Press (Forthcoming).
} 
products, or other matters, or conduct relating thereto ${ }^{9}$. This would including credit card and bank loan disputes. To meet the financial sector's interest in speedy proceedings, the Rules provide a limited period for arbitration proceedings with a maximum time frame of 120 days ${ }^{10}$. For disputes where only a small amount of money is involved (up to US\$75,000), an expedited procedure applies ${ }^{11}$, according to which a sole arbitrator will decide the dispute, preferably after only one day of hearing. If a second hearing is necessary, the rules provide that it shall take place within seven days of the first hearing. The award has to be rendered within thirty days of the conclusion of the hearing ${ }^{12}$.

${ }^{9}$ See r. 1 of the AAA Arbitration Rules for Commercial Financial Disputes:

'The parties to a dispute involving any commercial financial arrangement, product or other matter or conduct relating thereto, shall be deemed to have made these rules a part of their arbitration agreement whenever they have provided for arbitration by the American Arbitration Association (AAA) or under its Commercial Financial Disputes Arbitration Rules.'

${ }^{10}$ See r. 1, ibid:

'Consistent with the expedited nature of arbitration, the parties shall make every effort in good faith to conclude the arbitration within 120 days of its commencement.'

${ }^{11}$ See r. 9, ibid:

'Unless the AAA in its discretion determines otherwise or the parties agree otherwise, the Expedited Procedures shall be applied in any case where no disclosed claim or counterclaim exceeds $\$ 75,000$, exclusive of interest and arbitration costs.'

${ }^{12}$ S. Kratsch, 'The financial crisis: arbitration as a viable option for European financial institutions', Arbitration, 76(4) 2010, pp. 680-685.

For details of the expedited procedures, see rr. 51-55, ibid: '51. Notice by Telephone The parties shall accept all notices from the AAA by telephone. Such notices by the AAA shall subsequently be confirmed in writing to the parties. Should there be a failure to confirm in writing any notice hereunder, the proceeding shall nonetheless be valid if notice has, in fact, been given by telephone.

52. Appointment and Qualification of Arbitrator

(a) Where no disclosed claim or counterclaim exceeds $\$ 75,000$, exclusive of interest and arbitration costs, the AAA shall appoint a single arbitrator, from the National Roster, without submission of lists of proposed arbitrators.

(b) Where all parties request that a list of proposed arbitrators be sent, the AAA shall submit simultaneously to each party an identical list of five proposed arbitrators, drawn from the National Roster of Arbitrators, from which one arbitrator shall be appointed. Each party may strike two names from the list on a peremptory basis. The list is returnable to the AAA within seven days from the date of the AAA's mailing to the parties.

If for any reason the appointment of an arbitrator cannot be made from the list, the AAA may make the appointment from among other members of the National Roster without the submission of additional lists.

(c) The parties will be given notice by telephone by the AAA of the appointment of the arbitrator, who shall be subject to disqualification for the reasons specified in Section 17. Within seven days, the parties shall notify the AAA, by telephone, of any objection to the arbitrator appointed. Any objection by a party to the arbitrator shall be confirmed in writing to the AAA with a copy to the other party or parties.

53. Date, Time and Place of Hearing

The arbitrator shall set the date, time and place of the hearing. The AAA will notify the parties by telephone, at least seven days in advance of the hearing date. A formal notice of hearing will also be sent by the AAA to the parties.

54. The Hearing 
However, in a Securities Industry Conference on Arbitration pilot programme in 2000, in which investors were offered the option to file with JAMS or the AAA, investors selected the SRO's arbitration forum (such as FINRA) over non-SRO forums' higher fees and investors' 'general degree of comfort with existing and more familiar SRO procedures. ${ }^{, 13}$

\section{Challenges and Shortcomings of Mandatory Consumer Credit Card Arbitration}

Mandatory consumer credit card arbitration forums in the United States have been the focus of public litigation in recent years regarding alleged ties to credit card and collection industries. A recent consent decree issued in 2009 between Minnesota Attorney General Lori Swanson and the National Arbitration Forum ('Forum') - the country's largest administrator of credit card and consumer collections arbitrations, brought to light serious systemic issues including lack of impartiality and independence on the part of the National Arbitration Forum. It was found that the National Arbitration Forum 'worked alongside credit card companies to get them to put unfair arbitration clauses in the fine print of their contracts and to appoint the Forum as the arbitrator.' 14

The Forum, which was named as the arbitrator of consumer disputes in tens of millions of credit card agreements, according to the suit, allegedly hid from the public its extensive ties to the collection industry. ${ }^{15}$ The lawsuit alleged that the Forum worked behind the scenes to convince credit card companies and other creditors to insert arbitration provisions in their customer agreements and then appointed the Forum to decide the disputes. It also alleged that the company arbitrated 214,000 consumer arbitration claims in 2006, nearly 60 per cent of which were filed by laws firms with which the Forum was linked through ties to a New York hedge fund. ${ }^{16}$

Generally, the hearing shall be completed within one day, unless the dispute is resolved by submission of documents under Section 35. The arbitrator, for good cause shown, may schedule an additional hearing to be held within seven days.

55. Time of Award

Unless otherwise agreed by the parties, the award shall be rendered not later than 30 days from the date of the closing of the hearing.'

${ }^{13}$ Little, 'Fairness is in the eyes of the beholder', Baylor L. Rev., 60 (2008), p. 73.

${ }^{14}$ See: D. Gupta, 'Consent Decree in Minnesota v. NAF', Consumer Law \& Policy Blog, 20 July 2009, available at: http://pubcit.typepad.com/clpblog/2009/07/consent-decree-in-minnesota-v-naf.html [accessed 26 April 2012].

15 Ibid.

${ }^{16}$ Ibid. 
According to the terms of the settlement, the National Arbitration Forum agreed to stop accepting any new consumer arbitrations or in any manner participate in the processing or administering of new consumer arbitrations. The company will permanently stop administering arbitrations involving consumer debt, including credit cards, consumer loans, telecommunications, utilities, health care, and consumer leases. ${ }^{17}$

Such suits have brought to light the potential inequities existing behind the fine print of consumer agreements including mandatory pre-dispute arbitration clauses and have sparked United States Congressional interest and investigation. ${ }^{18}$

\section{Financial Dispute Resolution through FINRA}

In order to understand the role and function of the Financial Industry Regulatory Authority ('FINRA'), the most prominent nationwide program for the arbitration of consumer disputes with broker-dealers and financial institutions, it is necessary to examine its legislative and regulatory background.

\section{Arbitration of Securities Disputes - Securities Act 1933}

The Securities Act of 1933 was the first major piece of federal legislation governing securities. It combined a full disclosure scheme with antifraud provisions and the end product was federal statutory requirement to file a registration statement (prospectus) with Federal Trade Commission, imposing civil and criminal liabilities for failure to comply ${ }^{19}$

Although this created government and self-regulatory oversight, the general philosophy of the regulation of the sale of securities is 'buyer-beware', with Federal and state laws requiring that investors receive material information concerning securities being offered for public sale, and prohibit deceit, misrepresentation and other fraud ${ }^{20}$.

\footnotetext{
${ }^{17}$ Ibid.

${ }^{18}$ Ibid.

${ }^{19}$ C. W. Cole, 'Financial Industry Regulatory Authority (FINRA): is the consolidation of NASD and the regulatory arm of NYSE a bull or a bear for U.S. capital markets?', UMKC L. Rev., 76 (20072008), pp. 251-272.

${ }^{20}$ Powell, 'Business law: what Montana lawyers need to know about FINRA', Montana Lawyer, 33 (2008), p. 31 .
} 
The Securities Exchange Act of 1934 established the Securities Exchange Commission ('SEC') to regulate and enforce securities markets. It also contained disclosure provisions for those who buy and sell securities in the secondary market rather than the company's initial offerings, and creates remedies for fraud in trading and manipulating secondary markets ${ }^{21}$. The Act also requires stock exchanges to register with the $\mathrm{SEC}^{22}$.

The Maloney Act 1938 was an amendment to the 1934 Act, and requires registration by national securities associations of over-the-counter ('OTC') brokers and dealers with the SEC. The National Association of Securities Dealers ('NASD') was the only association to register ${ }^{23}$. The SEC was created by the 1934 Act and has broad regulatory authority to oversee the securities industry ${ }^{24}$.

\section{Self-Regulatory Organisations- FINRA}

Self-regulatory organisations ('SROs') are defined a non-governmental enties responsible for regulating its members through the adoption and enforcement of rules and regulations governing the business conduct of its members ${ }^{25}$.

Securities industry self-regulatory organisations began as private sector membership organisations of securities industry professionals. They set standards of conduct for their members and disciplined errant members. Securities industry SROs existed before the federal securities laws were enacted in 1933 and 1934, and important concepts of federal law were taken from SRO regulation and became an added layer of regulation on top of SRO regulation. Over the last seventy-five years, SROs have grown in membership and become more powerful organisations, but they also have become integrated into the scheme of federal statutory regulation, and now operate subject to SEC oversight of all of their activities. Moreover, as SROs have proliferated, some new SROs have been created by amendments to the securities

\footnotetext{
${ }^{21}$ C. W. Cole, 'Financial Industry Regulatory Authority (FINRA): is the consolidation of NASD and the regulatory arm of NYSE a bull or a bear for U.S. capital markets?'.

${ }^{22}$ Ibid.

${ }^{23} \mathrm{Ibid}$.

${ }^{24} \mathrm{Ibid}$.

${ }^{25}$ Ibid.
} 
laws. They are thus a peculiar mix of private sector self-regulation and delegated governmental regulation $^{26}$.

\section{National Association of Securities Dealers}

The National Association of Securities Dealers was formed in 1939 in response to the Maloney Act of 1938, which permitted a national association of securities brokers and dealers to self-regulate over-the-counter markets. It developed the National Association of Securities Dealers Automated Quotations ('NASDAQ') in 1971, which operates and has improved the quality and organisation of the OTC securities market, becoming the second largest stock market in the United States. NASD licensed over 665,000 individuals and oversaw 5,100 firms with over 170,000 branch offices, and set rules for firm and representative behaviour as well as disciplined firms and individuals who do not comply with NASD rules or SEC regulations ${ }^{27}$.

In 1994, the Rudman Committee was formed to review NASDAQ governance and operations, and concluded NASD and NASDAQ should separate to some degree, leading to NASD to sell the NASDAQ stock market in 2000 - NASD remains regulator of NADAQ by contract, and is still the only national securities association to register with SEC, hence retaining regulatory jurisdiction over any security not traded on an exchange ${ }^{28}$.

\section{Financial Industry Regulatory Authority}

The Financial Industry Regulatory Authority ('FINRA') on its face, is simply a consolidation of NASD and the enforcement and arbitration functions of NYSE Regulation. Although it combines the regulatory functions of an exchange with a securities association, many of the different provisions concerning stock exchanges and securities associations in the 1934 Act are similar, and it is thus feasible for one organisation to carry out the duties of both ${ }^{29}$.

\footnotetext{
${ }^{26}$ Karmel, 'Should securities industry self-regulatory organizations be considered government agencies?' Stan. J.L. Bus. \& Fin., 14 (2008), p. 151.

${ }^{27}$ Ibid.

${ }^{28} \mathrm{Ibid}$.

${ }^{29}$ Ibid.
} 
The stated purpose for the consolidation of the NASD and NYSE's regulatory arm is to bring more efficiency to securities industry regulatory efforts by creating a single rule book for broker-dealers. FINRA was designed as a monopoly SRO under the active and direct oversight of the SEC. Although FINRA may not be a government entity, in all or virtually all of its activities, it can be viewed as exercising powers delegated to it by the $\mathrm{SEC}^{30}$.

\section{Federal Arbitration Act}

The Federal Arbitration Act was passed by Congress in 1925, requiring courts to 'enforce arbitration agreements in the same manner as other contracts'

Section 2 of the $\mathrm{Act}^{32}$ declares irrevocable and enforceable written arbitration provisions in all maritime transactions and contracts 'involving commerce, ${ }^{33}$.

Wilko v. Swan 346 U.S. 427 (1953)

In the case of Wilko v. Swan the Supreme Court held that a pre-dispute agreement to arbitrate a claim under the Securities Act 1933 as being unenforceable for public policy reasons notwithstanding the existence of the Federal Arbitration Act. The Court felt that since there were risks that arbitrators would misapply law, which the judiciary would not be able to overturn under the Federal Arbitration Act, allowing securities arbitration would in effect allow claimants to waive provisions of the Securities $\mathrm{Act}^{34}$.

Shearson/American Express, Inc. v. McMahon 482 U.S. 220 (1987)

\footnotetext{
${ }^{30}$ Karmel, 'Should securities industry self-regulatory organizations be considered government agencies?'.

${ }^{31}$ B. B. Zoltowski, 'Restoring investor confidence: providing uniformity in securities arbitration by offering guidelines for arbitrators in deciding motions to dismiss before a hearing on the merits', Syracuse L. Rev., 58(3) (2008), pp. 375-396.

${ }^{32}$ Section 2 of the Act states that:

'A written provision in any maritime transaction or a contract evidencing a transaction involving commerce to settle by arbitration a controversy thereafter arising out of such contract or transaction, or the refusal to perform the whole or any part thereof, or an agreement in writing to submit to arbitration an existing controversy arising out of such a contract, transaction, or refusal, shall be valid, irrevocable, and enforceable, save upon such grounds as exist at law or in equity for the revocation of any contract.'

${ }^{33}$ J. I. Gross, 'The end of mandatory securities arbitration?', Pace L. Rev., 30 (2010), p. 1174.

${ }^{34}$ B. B. Zoltowski, 'Restoring investor confidence: providing uniformity in securities arbitration by offering guidelines for arbitrators in deciding motions to dismiss before a hearing on the merits'.
} 
In the case of Shearson/American Express, Inc. v. McMahon, the Supreme Court held that pre-dispute agreements to arbitrate were valid ${ }^{35}$.

The Court stated that Wilko v. Swan was decided under the Securities Act as opposed to the Exchange Act and that in any event Wilko v. Swan 'must be read as barring waiver of a judicial forum only where arbitration is inadequate to protect the substantive rights at issue.' The Court interpreted the provision against waiver in the Securities Exchange Act to only prohibit waiver of substantive rights, whereas, agreements to arbitrate just waived jurisdiction. Originally designed to provide 'a fast, efficient and cost-effective means of resolving securities disputes,' the SEC supported the Court's approval of securities arbitration agreements. The SEC felt arbitration would provide a forum in which investors could resolve small claims that did not justify the expense of litigation ${ }^{36}$.

Since then, virtually all customers' disputes with their broker-dealers and registered representatives are resolved through arbitration in the FINRA (or its predecessors NASD and NYSE) forum ${ }^{37}$.

Rodriguez de Quijas v. Shearson/American Express, Inc. 490 U.S. 477 (1989)

The case of Rodriguez de Quijas v. Shearson/American Express, Inc. was the Supreme Court case that expressly overruled Wilko v. Swan following Shearson/American Express, Inc. v. McMahon ${ }^{38}$.

Subsequent to the Shearson/American Express, Inc. v McMahon and Rodriguez de Quijas v. Shearson/American Express, Inc. decisions, the number of SRO securities arbitrations substantially increased ${ }^{39}$.

Arbitration Fairness Act 2009

In recent years, academics, media commentators and consumer advocates have questioned the use of pre-dispute arbitration clauses in consumer and employment

\footnotetext{
${ }^{35}$ Ibid.

${ }^{36}$ Ibid.

${ }^{37}$ B. Black, 'How to improve retail investor protection after the Dodd-Frank Wall Street Reform and Consumer Protection Act', U. Pa. J. Bus. L., 13 (2010), pp. 59-106.

${ }^{38} \mathrm{~S}$. Kratsch, 'The financial crisis: arbitration as a viable option for European financial institutions'.

${ }^{39}$ Little, 'Fairness is in the eyes of the beholder'.
} 
agreements, which result in class action waivers, inconvenient venue selection, costshifting provisions, and process limitations being forced on parties with inferior bargaining power. Courts usually enforce such clauses under the Federal Arbitration Act due to the Supreme Court's mandate that courts ruling on arbitrability questions must apply a presumption of arbitrability. Both the Senate and House introduced nearly identical bills to enact the Arbitration Fairness Act to reflect findings that the Federal Arbitration Act intended to apply to disputes between commercial entities of similar sophistication and bargaining power, but Supreme Court decisions have changed the meaning of the Federal Arbitration Act to extend to disputes between parties of disparate economic power. Furthermore, most consumers and employees have little or no meaningful option regarding whether to submit their claims to arbitration - a process that many argue undermines the development of public law for civil and consumer rights as there is no meaningful judicial review of arbitrator's decisions, and the process is not transparent ${ }^{40}$.

If passed by Congress, this Act would amend the Federal Arbitration Act to invalidate pre-dispute arbitration agreements requiring arbitration of employment, consumer, franchise and civil rights disputes. The Senate version of the Arbitration Fairness Act expressly extends its coverage to securities industry disputes through the definition of consumer disputes. However, Congress' legislative agenda for 2010 has placed the Arbitration Fairness Act on the backburner and focused on financial services regulatory reform ${ }^{41}$.

\section{Dodd-Frank Wall Street Reform and Consumer Protection Act}

The Dodd-Frank Wall Street Reform and Consumer Protection Act was a major reform bill that includes a provision that empowers the SEC to prohibit predispute arbitration agreements in customer agreements ${ }^{42}$.

Section 921 of the $\mathrm{Act}^{43}$ grants the SEC authority to limit or prohibit the use of pre-dispute arbitration agreements ${ }^{44}$.

\footnotetext{
${ }^{40}$ J. I. Gross, 'The end of mandatory securities arbitration?'.

${ }^{41}$ Ibid.

42 Ibid.

${ }^{43}$ Section 921 of the Act provides that:

“(a) Amendment to Securities Exchange Act of 1934- Section 15 of the Securities Exchange Act of 1934 (15 U.S.C. 78o), as amended by this title, is further amended by adding at the end the following new subsection:
} 


\section{FINRA Mandate and Function}

FINRA is now the largest non-governmental regulator for all securities firms doing business in the United States. It overseas nearly 5,100 brokerage firms, 173,000 branch offices and over 669,000 registered securities representatives ${ }^{45}$. Its role includes market oversight ${ }^{46}$, salesperson regulation ${ }^{47}$, investor education, enforcement and arbitration.

Investor Education, Enforcement and Arbitration

FINRA provides public educational materials that give a general overview of the securities industry and other basic information on securities intended to be accessible to laypersons ${ }^{48}$.

FINRA has authority to discipline licensed securities firms and registered individuals for breaches of rules and federal securities laws. Jurisdiction works in

'(o) Authority to Restrict Mandatory Pre-dispute Arbitration- The Commission, by rule, may prohibit, or impose conditions or limitations on the use of, agreements that require customers or clients of any broker, dealer, or municipal securities dealer to arbitrate any future dispute between them arising under the Federal securities laws, the rules and regulations thereunder, or the rules of a self-regulatory organization if it finds that such prohibition, imposition of conditions, or limitations are in the public interest and for the protection of investors.'.

(b) Amendment to Investment Advisers Act of 1940- Section 205 of the Investment Advisers Act of 1940 (15 U.S.C. 80b-5) is amended by adding at the end the following new subsection: '(f) Authority to Restrict Mandatory Pre-dispute Arbitration- The Commission, by rule, may prohibit, or impose conditions or limitations on the use of, agreements that require customers or clients of any investment adviser to arbitrate any future dispute between them arising under the Federal securities laws, the rules and regulations thereunder, or the rules of a selfregulatory organization if it finds that such prohibition, imposition of conditions, or limitations are in the public interest and for the protection of investors.'."

${ }^{44}$ B. Black, 'How to improve retail investor protection after the Dodd-Frank Wall Street Reform and Consumer Protection Act'.

${ }^{45}$ Powell, 'Business law: what Montana lawyers need to know about FINRA'.

${ }^{46} \mathrm{Ibid}$. FINRA oversees and regulates trading on a national level, including NASDAQ, the American Stock Exchange, the International Securities Exchange, the Chicago Climate Exchange in the OTC markets, as well as trades in NYSE and Amex-listed securities reported to NASDAQ. It also regulates trading in the corporate bond markets. Corporate bond transactions are reported to FINRA's Trade Reporting and Compliance Engine ('TRACE') and are disseminated to the public.

${ }^{47}$ Ibid. FINRA oversees background checks, examinations, licensing and oversight of licensed securities salespersons. It also operates a central licensing and registration system for USA securities industry and regulators, contains the registration records of more than 6,800 registered broker-dealers and the qualification, employment, and disclosure histories of more than 660,000 active registered individuals (salespersons).

${ }^{48}$ Powell, 'Business law: what Montana lawyers need to know about FINRA'. 
coordination with the dual federal-state jurisdiction that gives authority to the SEC and the state regulators to regulate the members of the securities industry through administrative, civil and criminal filings ${ }^{49}$.

The majority of contracts between salesperson, broker-dealer firms and customers include an arbitration requirement, and most contractual disputes go through an arbitration process. Though there are several organisations that could handle securities arbitrations, the majority of security disputes are handled by FINRA according to its rules and regulations for arbitration ${ }^{50}$.

Compulsory arbitration between member firms and member firms and their employees has generally been viewed as a matter of private contract, a condition of being a member of an $\mathrm{SRO}^{51}$.

Even if a customer agreement does not contain a pre-dispute arbitration clause, the FINRA Code of Arbitration Procedure for Customer Disputes Rule $12200^{52}$ requires broker-dealers to submit to arbitration at the demand of a customer ${ }^{53}$.

In addition to the more formal arbitration procedure, FINRA offers a nonbinding mediation program. During the period 2005-7, according to FINRA's statistics, approximately 70-80 per cent of claims filed were settled or resolved through means other than an arbitrator decision, 3-4 per cent of cases were resolved by arbitrators on the basis of written submissions, and 18-20 per cent of cases were resolved after a formal hearing ${ }^{54}$.

\section{Underlying Legal Mandate}

The primary function of SROs is the regulation of broker-dealers, serving as intermediaries between the SEC and regulated members of the industry. A broker is

\footnotetext{
${ }^{49}$ Ibid.

${ }^{50}$ Ibid.

${ }^{51}$ Karmel, 'Should securities industry self-regulatory organizations be considered government agencies?'.

${ }^{52}$ Rule 12200 provides that:

'Parties must arbitrate a dispute under the Code if:

- Arbitration under the Code is either:

(1) Required by a written agreement, or

(2) Requested by the customer;

- The dispute is between a customer and a member or associated person of a member; and

- The dispute arises in connection with the business activities of the member or the associated person, except disputes involving the insurance business activities of a member that is also an insurance company.'

${ }^{53}$ J. I. Gross, 'The end of mandatory securities arbitration?'.

${ }^{54}$ S. Choi, J. E. Fisch and A. C. Pritchard, 'Attorneys as arbitrators', J. Legal Stud., 39 (2010), p. 109.
} 
defined as 'any person engaged in the business of effecting transactions in securities for the account of others,' and a dealer as 'any person engaged in the business of buying and selling securities for such person's own account.' Many firms operate as both brokers and dealers. The Securities Exchange Act requires broker-dealers to register with the SEC and join either a registered national securities exchange or an $\mathrm{SRO}^{55}$.

The authority granted to FINRA under the Exchange Act allows it to be an effective intermediary between the SEC and its registered broker-dealers. While the SEC does not have the general authority to adopt rules governing the conduct of registered broker-dealers in relation to their customers, FINRA, and other SROs like it, require their members to adopt rules of conduct and to retain the power to enforce these rules (and other supervisory policies and procedures) using designated enforcement and examination staff ${ }^{56}$.

\section{Types of Dispute}

\section{Procedure}

FINRA administers 'the largest [US] dispute resolution forum for investors and registered firms.' FINRA Dispute Resolution ('FINRADR') provides both mediation and arbitration, and suggests, but does not require, that an aggrieved investor first attempt to resolve the conflict with the brokerage firm's management. The FINRA Code of Arbitration Procedure for Customer Disputes applies to any dispute between a customer and a member that is submitted to arbitration ${ }^{57}$.

Once an investor is compelled to arbitrate a claim, the modern process is akin to litigation with only slight variation. Arbitration, despite being touted as a 'quick, fair, and relatively inexpensive' alternative to litigation, employs similarly formal procedures that can increase costs and cause delays. First, the complainant files an initial statement of claim with the Director of Dispute Resolution, 'specifying the relevant facts and remedies requested.' The respondent then serves an answer

\footnotetext{
${ }^{55}$ J. T. Koebel, 'Trust and the investment adviser industry: Congress' failure to realize FINRA's potential to restore investor confidence', Seton Hall Legis. J., 35 (2010), p. 61.

${ }^{57}$ C. Alpert, 'Financial Services in the United States and United Kingdom: Comparative Approaches to Securities Regulation and Dispute Resolution', BYU Int'l L. \& Mgmt. Rev., 5 (2008), p. 75.
} 
including relevant facts, available defences and any counterclaims. A panel, usually consisting of three arbitrators, is appointed to consider the initial statement of claim and all responsive pleadings. Similar to litigation, the parties are subject to a discovery process including depositions, motion hearings on disputed collateral matters, and possible sanctions for failure to comply with any of the FINRA Code requirements. The parties produce witnesses and the arbitrators have the authority to issue subpoenas where necessary to compel production of documents or persons to appear. Except in certain circumstances, parties present their evidence in the form of testimony and documents in a litigation-like hearing before the arbitral panel. Unlike litigation, however, evidence is admissible notwithstanding state or federal evidence rules, although witnesses must testify under oath or affirmation ${ }^{58}$.

Financial Industry Regulatory Authority rules establish two categories of arbitrators - public and non-public (industry). Under the current procedures, claims for less than US\$25,000 are resolved through a simplified procedure involving a single arbitrator who resolves the case without a formal hearing. Claims for between US $\$ 25,000$ and US $\$ 50,000$ receive a hearing conducted by a single arbitrator, although any party has the right to request a three-person panel. If the claim is heard by a single arbitrator, FINRA rules require that the arbitrator be a public arbitrator unless the parties agree otherwise. Claims for US\$50,000 or more are resolved by a panel consisting of three arbitrators. If the case is heard by a three-person panel, the rules provide that the panel will be composed of two public arbitrators and one nonpublic (industry) arbitrator ${ }^{59}$.

Current and former professionals in the securities industry and other professionals with substantial industry ties may not be classified as public arbitrators (Uniform Code of Arbitration, FINRA Code r. 10308[a][5] ${ }^{60}$ ). Public arbitrators are

\footnotetext{
${ }^{58}$ Ibid.

${ }^{59}$ S. Choi, J. E. Fisch and A. C. Pritchard, 'Attorneys as arbitrators'.

${ }^{60}$ FINRA Rule 10308[a][5] states that:

'(5) "public arbitrator"

(A) The term "public arbitrator" means a person who is otherwise qualified to serve as an arbitrator and:

(i) is not engaged in the conduct or activities described in paragraphs (a)(4)(A) through (D);

(ii) was not engaged in the conduct or activities described in paragraphs (a)(4)(A) through (D)

for a total of 20 years or more;

(iii) is not an investment adviser;

(iv) is not an attorney, accountant, or other professional whose firm derived 10 percent or more of its annual revenue in the past 2 years from any persons or entities listed in paragraph (a)(4)(A);

(v) is not employed by, and is not the spouse or an immediate family member of a person who
} 
thus intended to be industry outsiders or 'neutrals'. Non-public arbitrators, commonly known as industry arbitrators, include current and former brokers, bankers, and other securities professionals. The category also includes attorneys, accountants, and other professionals who have devoted 20 per cent or more of their professional work to industry clients (Uniform Code of Arbitration, FINRA Code r. 10308[a][4] ${ }^{61}$ ).

Arbitrators for FINRA arbitrations are chosen through a list selection system administered by the director of dispute resolution, termed the Neutral List Selection System ('NLSS'). The lists are generated by an NASD computer program using a rotational method, although the computer eliminates arbitrators with obvious conflicts of interest. Along with the lists, the parties are also provided with background information on each arbitrator, including a copy of that arbitrator's Arbitrator Disclosure Report. Parties are allowed to request additional information about the arbitrators $^{62}$.

is employed by, an entity that directly or indirectly controls, is controlled by, or is under common control with, any partnership, corporation, or other organization that is engaged in the securities business;

(vi) is not a director or officer of, and is not the spouse or an immediate family member of a person who is a director or officer of, an entity that directly or indirectly controls, is controlled by, or is under common control with, any partnership, corporation, or other organization that is engaged in the securities business; and

(vii) is not the spouse or an immediate family member of a person who is engaged in the conduct or activities described in paragraphs (a)(4)(A) through (D).

(B) For purposes of this Rule, the term "immediate family member" means:

(i) a person's parent, stepparent, child, or stepchild;

(ii) a member of a person's household;

(iii) an individual to whom a person provides financial support of more than 50 percent of the individual's annual income; or

(iv) a person who is claimed as a dependent for federal income tax purposes.'

${ }^{61}$ FINRA Rule 10308[a][4] states that:

'(4) "non-public arbitrator"

The term "non-public arbitrator" means a person who is otherwise qualified to serve as an arbitrator and:

(A) is, or within the past 5 years, was:

(i) associated with, including registered through, a broker or a dealer (including a government securities broker or dealer or a municipal securities dealer);

(ii) registered under the Commodity Exchange Act;

(iii) a member of a commodities exchange or a registered futures association; or

(iv) associated with a person or firm registered under the Commodity Exchange Act;

(B) is retired from, or spent a substantial part of a career, engaging in any of the business activities listed in subparagraph (4)(A);

(C) is an attorney, accountant, or other professional who has devoted 20 percent or more of his or her professional work, in the last two years, to clients who are engaged in any of the business activities listed in subparagraph (4)(A); or

(D) is an employee of a bank or other financial institution and effects transactions in securities, including government or municipal securities, and commodities futures or options or supervises or monitors the compliance with the securities and commodities laws of employees who engage in such activities.'

${ }^{62}$ S. Choi, J. E. Fisch and A. C. Pritchard, 'Attorneys as arbitrators'. 
The chair of the panel is typically responsible for the overall administration of the proceeding, including the resolution of discovery disputes, ruling on evidentiary issues, etc. Parties have the right, in the first instance, to designate the chair of the panel by agreement, although, according to FINRA, the parties agree on the designation of the chair only 20 per cent of the time. If the parties are unable to agree, the chair is appointed by the director and is to be the public arbitrator who received the highest combined ranking 'as long as the person is not an attorney, accountant, or other professional who has devoted 50 [per cent] or more of his or her professional or business activities, within the last two years, to representing or advising public customers in matters relating to disputed securities or commodities transactions or similar matters' (Uniform Code of Arbitration, FINRA Code, Rule $10308[\mathrm{c}][5][\mathrm{A}])$.

Unlike the United Kingdom or Australia, since FINRA complainants must pay an arbitration fee, a hearing deposit, and attorneys' fees, cost-deterrence serves as a filter, and therefore strict jurisdictional prerequisites for arbitration are unnecessary ${ }^{63}$.

Awards

If the parties proceed to an award, the FINRA Code requires that a majority of arbitrators agree on the rulings and determinations, but it does not require written opinions. 'Awards are subject to judicial review on the merits' only for 'manifest disregard' of the law and 'do not serve as precedent'. ${ }^{64}$ This limited judicial review and absence of a required reasoned opinion allows arbitrators to base awards in favour of claimants on 'general equity grounds'. ${ }^{65}$

FINRA Arbitration has no statutory cap on the value of awards, but incorporates a small-claims procedure, by which it diverts claims for US\$25,000 or less to a Simplified Arbitration Procedure. Unless the customer requests a hearing, such claims are decided solely on the parties' written submissions. ${ }^{66}$

Fees

\footnotetext{
${ }^{63}$ C. Alpert, 'Financial Services in the United States and United Kingdom: Comparative Approaches to Securities Regulation and Dispute Resolution'.

${ }^{64} \mathrm{Ibid}$.

${ }^{65} \mathrm{Ibid}$.

${ }^{66}$ Ibid.
} 
FINRADR is administered by FINRA, and is funded by regulatory fees from FINRA members, dispute resolution fees from users, as well as other fees from FINRA's regulatory role.

\section{Oversight}

The SEC exercises oversight authority over FINRA as the SRO for brokerdealers, which is the principal regulator ${ }^{67}$.

SROs set rules governing member firms in the financial industry and provide oversight, supplementing that of the SEC. 8 SROs report to the SEC, which subjects SRO rules to an approval process ${ }^{68}$.

The SEC provides little oversight over FINRA arbitration. Little oversight by the SEC combined with the court's grant of nearly limitless power to arbitrators makes investor protection uncertain at best ${ }^{69}$.

\section{Strengths}

The advantage of securities arbitration from a retail investors' perspective is that they may be able to recover damages despite the unavailability of a legal remedy, and emphasis of the FINRA arbitration forum on equity allows arbitrators to fashion a remedy for investors that may not be supported by the law ${ }^{70}$.

The pre-dispute arbitration agreement also provides reasonable notice, the right to retain counsel and to present evidence, a convenient geographical location for the evidentiary hearing, and the right to adequate relief. Arbitration with FINRA generally allows the claimant to have the dispute resolved in a timelier manner than litigation. Moreover, the statutes of limitations in many jurisdictions are substantially shorter than the NASD Customer Code's six-year eligibility rule - an investor claim

\footnotetext{
${ }^{67}$ B. Black, 'How to improve retail investor protection after the Dodd-Frank Wall Street Reform and Consumer Protection Act'.

${ }^{68}$ J. T. Koebel, 'Trust and the investment adviser industry: Congress' failure to realize FINRA's potential to restore investor confidence'.

${ }^{69}$ B. B. Zoltowski, 'Restoring investor confidence: providing uniformity in securities arbitration by offering guidelines for arbitrators in deciding motions to dismiss before a hearing on the merits'.

${ }^{70} \mathrm{~B}$. Black, 'How to improve retail investor protection after the Dodd-Frank Wall Street Reform and Consumer Protection Act'.
} 
filed in civil litigation might be more likely dismissed upon these grounds, whereas in arbitration the investor might have been awarded a substantial portion of his or her compensatory damages regardless of the statutes of limitations ${ }^{71}$.

FINRA Arbitration also offers finality benefits for either side when successful $^{72}$.

\section{Challenges}

\section{Harmonisation}

Following the merger of NASD and NYSE Regulation, there has been the challenge of how the rules of the two organisations should be merged and harmonised, raising the issue of whether FINRA should continue with rules-based regulation or move to a principle-based or tier-based approach ${ }^{73}$.

\section{Bank Broker-Dealers}

FINRA recently proposed to adopt a modified version of NASD Rule 2350, known as the 'bank broker-dealer rule'. The proposed rule change seeks to prevent FINRA member firms that offer broker-dealer products and services through contractual 'networking arrangements' with financial institutions - both on and off the premises of those institutions - from undertaking certain business practices that might tend to confuse or harm customers of financial institutions. The proposed rule change also aims to prevent customer confusion by, inter alia, ensuring that certain disclosures are made to customers so they can understand and appreciate the distinction(s) between the products and services sold by a financial institution and those sold by its broker-dealer affiliate ${ }^{74}$.

The proposed rule change protects bank customers who may be solicited for the purchase of investment products and services, but only to a limited extent. It does

\footnotetext{
${ }^{71}$ Little, 'Fairness is in the eyes of the beholder'.

${ }^{72}$ C. Alpert, 'Financial Services in the United States and United Kingdom: Comparative Approaches to Securities Regulation and Dispute Resolution'.

${ }^{73}$ C. W. Cole, 'Financial Industry Regulatory Authority (FINRA): is the consolidation of NASD and the regulatory arm of NYSE a bull or a bear for U.S. capital markets?'.

${ }^{74}$ J. I. Gross and E. Pekarek, 'Banks and brokers and bricks and clicks: an evaluation of FINRA's proposal to modify the "bank broker-dealer rule", Alb. L. Rev., 73 (2010), p. 465.
} 
not rectify sales practices of broker-dealers - affiliated with financial institutions which tend to confuse, and even mislead, financially unsophisticated investors of modest means who can least afford to be exposed to excessive risk. ${ }^{75}$ Additionally, the proposed rule change adds no meaningful surveillance, inspection, enforcement, or punitive mechanisms to prevent and/or redress insidious practices that are akin to 'bait and switch' tactics and are particularly effective against financially unsophisticated investors. ${ }^{76}$ In fact, the proposed rule change even rolls back some key regulatory provisions, an especially unsettling retreat when one considers the lack of oversight during the recent market malaise and the contribution that such abridgement may have made to the present economic contraction as a reverse "wealth effect' impinges upon consumer behaviour. It is arguable that the proposed rule change is inadequate to sufficiently protect investors and promote genuine market integrity ${ }^{77}$.

\section{Challenge to Mandatory Securities Arbitration}

As noted above, the passage of the Arbitration Fairness Act would extend to predispute arbitration agreements in the securities industry. Furthermore, the SEC has now been empowered to prohibit such clauses in customer agreements.

Investor advocates argue securities arbitration is unfair, inefficient, expensive and biased towards the securities industry, whilst the securities industry argues the process works well, is faster and less expensive than litigation, and is fair to all parties involved $^{78}$.

It has been argued that because securities arbitration differs from other forms of consumer arbitration, the power of the SEC should not be exercised and the Arbitration Fairness Act should not be extended to the securities industry. In this regard, it has been pointed out that the SEC robustly exercises its authority to oversee FINRA, including its dispute resolution arm, while no administrative agency reviews consumer or non-securities employment arbitration forums. FINRA Conduct Rule 3110(f) prescribes language that member firms must include in their customer agreements, and precludes brokerage firms from including unfair provisions, or

${ }^{78}$ J. I. Gross, 'The end of mandatory securities arbitration?’.
} 
provisions that limit a customer's rights and remedies. FINRA bars brokerage firms from imposing class action waivers, and FINRA Dispute Resolution does not permit class arbitrations, thus freeing investors to pursue class action claims in court. FINRA's Code of Arbitration Procedure for Customer Disputes contains provisions that expressly contradict the types of unfair consumer arbitration provisions that the Arbitration Fairness Act targets, and FINRA actively facilitates forum access by subsidising forum fees and reducing costs to lower levels than consumer arbitration and other measures. It also actively promotes transparency of the process and recently amended its rues to require arbitrators to write an explained decision if all parties jointly request one. FINRA also ensures where an arbitration panel awards damages, the investor will collect the damages promptly.

Furthermore, in giving investors a choice between arbitration and litigation, investors may face a more hostile environment in court, as well as facing significant procedural hurdles, in contrast with the equitable principles an arbitration panel can employ. Given the high costs of litigation, firms may decline post-dispute requests for arbitration, especially in smaller cases, discouraging customers from pursuing claims altogether. Elimination of mandatory securities arbitration could result in higher transaction costs as firms would need to account for higher costs to litigate rather than arbitrate. There is also empirical evidence to show that investors may not choose their forum of dispute resolution rationally or even make the choice in their best interests. Eliminating mandatory securities arbitration could also lead to the repeal of Rule 12200 of the FINRA Code of Arbitration Procedure for Customer Disputes $^{79}$, which allows customers to demand broker-dealers submit to arbitration. Optional arbitration would also reduce political pressure on FINRA to ensure the fairness of the forum. ${ }^{80}$

\section{Explained Decisions}

On 15 March 15 2005, the NASD filed a proposed rule with the SEC to provide written explanations in arbitration awards upon the request of customers, or from a request by associated persons involved in industry controversies. The NASD surprisingly admitted that the lack of an explained decision made it 'all but impossible

\footnotetext{
${ }^{79}$ For Rule 12200 , see footnote 52 above.

${ }^{80}$ Ibid.
} 
[for the judiciary] to determine whether [the panel] acted with manifest disregard of the law.' To date, the SEC has not yet ruled upon FINRA's 2005 proposed rule regarding explained decisions. However, given FINRA's recently proposed rule amendments requiring an explanatory decision accompanying an order of dismissal for a dispositive motion filed before the end of a claimant's case, it is clear that the SEC will soon have to address the issue of explained decisions in the context of securities arbitrations ${ }^{81}$.

\section{Non-adherence with Procedures}

Many practitioners doubt the fairness of the SRO arbitration process, believing that the limited document and information discovery afforded under the NASD Customer Code is difficult to obtain due to the securities industry having little respect for complying with NASD discovery procedures because they simply do not believe that an arbitration panel will be as likely as a sitting judge to sanction them for their discovery violations and related behaviour ${ }^{82}$.

\section{Cost and Complexity}

Observers have noted that the NASD Code of Arbitration no longer reflects a simple, efficient medium for the economical resolution of securities disputes. Instead it exhibits the characteristics of the Federal Rules of Civil Procedure but without the procedural safeguards of full discovery, fair award of costs to the prevailing party, explanatory orders, a sitting judge, and appellate review. ${ }^{83}$ The practice of securities arbitration is more contentious than in previous times, arguably due to the lack of judicial oversight. Given the substantial filing fees, pre-hearing and hearing costs levied by the NASD - from a pure cost of recovery perspective - litigation has become a relative bargain. ${ }^{84}$ It is not atypical for a four-day arbitration evidentiary hearing, coupled with the costs of pre-hearing conferences, to produce fees and expense billings from the NASD totalling substantially in excess of US $\$ 10,000$. Factoring in the tendency of arbitration panels to 'split the baby', whether it relates to

\footnotetext{
${ }^{81}$ Little, 'Fairness is in the eyes of the beholder'.

${ }^{82}$ Ibid.

${ }^{83}$ Ibid.

${ }^{84}$ Ibid.
} 
arbitration fees and expenses or to the actual award provided to the 'successful' claimant, the claimant's net recovery may be reduced to a fraction of what may have been awarded in litigation by a judge or a jury strictly adhering to a judge's instructions on the law ${ }^{85}$. This substantial potential expense stands as both a psychological and monetary barrier to the FINRA arbitration forum for many defrauded investors. Although FINRA may waive its fees based on a showing of 'hardship', this waiver is not automatically given and the final determination of hardship is customarily not decided prior to incurring the hearing expenses.

\section{Lessons Learnt}

Congress requested the United States General Accountability Office ('GAO') to evaluate SRO arbitration relating to concerns held by Congress, state regulators, and investor groups 'about whether industry-sponsored arbitration is fair to investors', with a primary concern that 'arbitration at an industry-sponsored forum may have a pro-industry bias'. The GAO issued an initial study in 1992 (the 1992 GAO Report) finding that there existed no industry bias at industry sponsored forums versus independent forums, but made no finding regarding the overall 'fairness' of the arbitration process due to the limited number of customer disputes being litigated and the inherent differences between the litigation and arbitration processes. The 1992 GAO Report did find that, at the time, the SROs lacked internal controls sufficient to reasonably assure that SRO arbitrators were either independent or competent. In particular, the 1992 GAO Report found that the SROs had no formal standards to qualify arbitrators, performed no background verification regarding information provided by the arbitrators, and had no system to properly train arbitrators to function fairly and appropriately. A subsequent GAO study in 2000 included positive findings regarding the SROs' implementation of the 1992 GAO Report's recommendations allowing arbitration parties a greater role in arbitrator selection, verifying arbitrator background information, and improving arbitrator training ${ }^{86}$.

Securities arbitration has consistently been criticised as favouring the securities industry over the interests of investors. The NASD created the Arbitration Policy Task Force in 1994 to evaluate and respond to a number of criticisms, including

\footnotetext{
${ }^{85} \mathrm{Ibid}$.

${ }^{86}$ Ibid.
} 
claims that the system was biased or industry dominated. Although the NASD's task force found no evidence of bias, a number of its recommendations were designed to improve the perceived and actual fairness of the system, leading to rule changes in 2004 and 2007 including more stringent arbitrator requirements for updating disclosures ${ }^{87}$.

\section{Investor Perception}

Empirical evidence shows (1) investors have a far more negative perception of securities arbitration than all other participants, (2) investors have a strong negative perception of the bias of arbitrators in the securities arbitration forum, and (3) investors lack knowledge of the securities arbitration process ${ }^{88}$. Gross and Black's 2008 study concluded that 'Despite FINRA's commendable efforts to improve the process, these efforts will likely prove unsuccessful in winning customers' confidence so long as they are required to accept both an industry arbitrator and an unexplained award.' Among the findings of the study included ${ }^{89}$ :

- $\quad 40.4$ per cent of the customers who responded either disagreed or strongly disagreed with the proposition that their arbitration panel was open-minded.

- 70.77 per cent of the customers who responded either disagreed or strongly disagreed with the proposition that they were satisfied with the outcome.

- $\quad 49.13$ per cent of the customers who responded either agreed or strongly agreed that the arbitration process was too expensive.

\footnotetext{
${ }^{87}$ S. Choi, J. E. Fisch and A. C. Pritchard, 'Attorneys as arbitrators'.

${ }^{88}$ J. I. Gross and B. Black, 'When perception changes reality: an empirical study of investors' views of the fairness of securities arbitration', J. Disp. Resol., 2 (2008), p. 349.

${ }^{89} \mathrm{Ibid}$. The findings also included:

40.58 per cent of the customers who responded either disagreed or strongly disagreed with the proposition that their arbitration panel was impartial.

55.48 per cent of the customers who responded either agreed or strongly agreed with the proposition that they would be more satisfied if they had an explanation of the award.

51.55 per cent of the customers who responded either disagreed or strongly disagreed with the proposition that they would recommend to others that they use arbitration to resolve their securities disputes.

62.62 per cent of the customers who responded either disagreed or strongly disagreed with the proposition that they, as a whole, feel that the arbitration process was fair.

49.2 per cent of the customers who responded either disagreed or strongly disagreed with the proposition that arbitration was without bias for all parties.
} 
- 60 per cent of the customers who responded either disagreed or strongly disagreed with the proposition that they have a favourable view of securities for customer disputes.

- $\quad 61.3$ per cent of the customers who responded either disagreed or strongly disagreed with the proposition that arbitration was fair for all parties.

However, it has been argued that changes to investor perception of the fairness of the FINRA arbitral process may have been caused by the market itself, and the fact that in a period of market instability, more awards and damages are likely to go in favour of investors than in a period of stability - ironically, what is likely is that in light of the 2008 Market Crash, investors will receive larger and more frequent awards. Therefore, it is likely that in a follow up survey inquiring about the securities arbitration Forum, an investor survey will likely find that the users of the Forum believe the present form of the Forum is fair. ${ }^{90}$

\section{Arbitrator Conflicts of Interest and Bias}

Empirical evidence also shows arbitrators who also represent brokerage firms or brokers in other arbitrations award significantly less compensation to investorclaimants than do other arbitrators ${ }^{91}$.

In 1992, the General Accounting Office (1992) published the results of a study of arbitration awards during an eighteen-month period in 1989 and 1990. The GAO found that claimants received an award of monetary damages in 59 per cent of arbitrations and received, on average, 61 per cent of claimed damages. In 2000, the GAO published an updated report that reflected data from 1992 to 1998. That study found that investors' win rates had declined to an average of 51 per cent over the time period but reasoned that this decline might be the result of an increase in settled claims rather than a pro-industry bias. More recent data indicate that the investor win rate has continued to decline. Statistics from FINRA show that investors received an award of monetary damages or other nonmonetary relief in 42 per cent of the cases decided in 2006 and in 37 per cent in $2007^{92}$.

\footnotetext{
${ }^{90}$ S. D. Grannum, 'The faith and face of securities arbitration: after the 2008 crash' in D. E. Robbins (ed.), Securities Arbitration in the Market Meltdown Era, (Practising Law Institute: New York, 2009), Chapter 4.

${ }^{91}$ S. Choi, J. E. Fisch and A. C. Pritchard, 'Attorneys as arbitrators'.

${ }^{92}$ Ibid.
} 
There is a long-held view by many practitioners that arbitrators, after finding the brokerage firm liable to the investor, are prone to 'split the baby' when deciding the amount of compensatory damages to be paid by the securities industry in an effort to placate the industry arbitrator, and to increase the likelihood that industry respondents will not strike arbitrators (public or industry) from serving on future arbitration panels. Moreover, there is the view that arbitration panels judge the securities industry's major broker-dealers with greater leniency than their smaller broker-dealer brethren. These perceptions find a statistical foundation by a study recently released by Edward S. O'Neal, Ph.D, a former Assistant Finance Professor at Wake Forest University's Babcock Graduate School of Management, and investor representative Daniel R. Solin, Esq ${ }^{93}$.

The O'Neal-Solin Report also disclosed that the greater the compensatory dollar amount requested, or the larger the size of the brokerage firm named as the respondent, the smaller the expected recovery percentage for the investor tends to be on average. In fact, the larger size of the broker-dealer and the compensatory amount claimed can dramatically reduce the likelihood for recovery and the percentage amount recovered. ${ }^{94}$

The arbitration selection process may also be subject to the appearance of bias emanating from the mandated industry arbitrator. Efforts by FINRA to alleviate this problem by changing the rules to allow for the option of all-public panels in FINRA arbitrations, however, have been met with criticism by industry experts, who cite the potential for increased costs due to reliance on an expert witness rather than the expertise of an industry panellist ${ }^{95}$.

Another characteristic which casts doubt upon the fairness of arbitration is the lack of adequate judicial review resulting from the standard of 'manifest disregard' for the law. In essence, a party must basically prove arbitrator misconduct in order to have the award vacated ${ }^{96}$.

In the context of the perceptions of bias in the arbitral process, it has been argued that the inability of investors to effectively enforce property rights through a more efficient mechanism, whether it be through litigation, arbitration, binding

\footnotetext{
${ }^{93}$ Little, 'Fairness is in the eyes of the beholder'.

${ }^{94}$ Ibid.

${ }^{95}$ L. Konish, 'All-public Panels Approved For Arbitrations; A step in the right direction-or just a cost increase?', onwallstreet, 1 March 2011, available at: www.onwallstreet.com/ows_issues/2011_3/allpublic-panels-approved-for-arbitrations-2671609-1.html [accessed 8 February 2012].

${ }^{96}$ Ibid.
} 
mediation through a neutral third party, or an administrative law judge, leads to market inefficiency, which is detrimental to the health of an economic system. In the short run, market inefficiencies benefit only those few who encourage them while in the long run they are harmful to the overall economy. ${ }^{97}$ Often it is the small investor bringing his claim in a court of law or arbitral institution that serves as the early warning system of wide-spread wrong-doing. Increased transparency, sensible regulation, and the ability of the individual investor to enforce his or her property rights in a court of law are important components of any solution to preventing future economic instability. ${ }^{98}$

\footnotetext{
${ }^{97}$ B. Stark, 'Compulsory arbitration: its impact on the efficiency of markets', in D. E. Robbins (ed.), Securities Arbitration in the Market Meltdown Era, (Practising Law Institute: New York, 2009), Chapter 9.

${ }^{98}$ Ibid.
} 


\section{Study Results}

In order to assess how arbitrators and ombudsmen view the benefits, challenges and suggestions for the improvement of both ombuds and arbitration processes in the context of consumer financial dispute resolution, a survey was conducted between the Fall of 2011 and the Summer of 2012. Nearly a hundred survey questionnaires were distributed to practitioners throughout the world. A total of forty-eight arbitrators and ombuds people from East Asia, North America, Europe, the Middle East and Africa responded. The participants represented highly experienced practitioners, members of government regulatory ombuds services and private arbitration commissions. The majority of those surveyed (44 per cent) had worked for institutions involved in consumer financial dispute resolution for more than four years.

First, in examining the effect of method of practice, whether arbitration or ombuds on the relative upward or downward trend in usage, the author finds no statistically significant variation between the two methods. In general, both the use of arbitration and ombuds services are on the increase. Only a slightly higher proportion of respondents noted that arbitration was on the decline in comparison with ombuds practices. This finding requires further elaboration as will be examined below.

Table 1: Increase or Decrease in Usage by Method of Practice (\%), 2012

\begin{tabular}{|l|rr|r|}
\hline Response & Method & Total \\
\cline { 2 - 4 } & Arbitration & Ombuds & \\
\hline Decrease & 1 & 0 & 1 \\
& 5.88 & 0.00 & 4.00 \\
Increase & 16 & 8 & 24 \\
& 94.12 & 100.00 & 96.00 \\
\hline Total & 17 & 8 & 25 \\
& 100.00 & 100.00 & 100.00 \\
\hline
\end{tabular}

Note: Pearson chi2 $(1)=0.4902 \quad \operatorname{Pr}=0.484$

Second, the study examined the effect of the method of practice on general settlement rate. Again, no statistically significant variation could be found between the two methods and their effect on settlement. In general, the large majority of 
settlement rates resulting from arbitration and ombuds processes are greater than $50 \%$. That being said, the results indicate a slightly higher overall settlement rate through use of the ombuds process. These findings will be examined more fully on the basis of the results of open-ended survey data below.

Table 2: Settlement Rate by Method of Practice (\%), 2012

\begin{tabular}{|l|rr|r|}
\hline Response & Method & Total \\
\cline { 2 - 4 } & Arbitration & Ombuds & \\
\hline Less than 50\% & 9 & 2 & 11 \\
& 34.62 & 22.22 & 30.56 \\
More than $50 \%$ & 17 & 7 & 25 \\
& 65.38 & 77.78 & 69.44 \\
\hline Total & 26 & 9 & 36 \\
& 100.00 & 100.00 & 100.00 \\
\hline
\end{tabular}

Note: Pearson chi2 $(1)=0.9365 \operatorname{Pr}=0.626$

Finally, the study examined relative user satisfaction by method of practice. Again, no statistically significant variation could be found between the two methods. A slightly higher level of perceived satisfaction was reported for arbitration practice, though this might be largely explained by sample selection bias, given that arbitration practitioners are asked to self-report perceived user satisfaction with the process.

Table 3: User Satisfaction by Method of Practice (\%), 2012

\begin{tabular}{|l|rr|r|}
\hline Response & Method & Total \\
\cline { 2 - 4 } & Arbitration & Ombuds & \\
\hline Unsatisfied & 2 & 3 & 5 \\
& 9.52 & 33.33 & 16.3 \\
Satisfied & 19 & 6 & 26 \\
& 90.48 & 66.67 & 83.87 \\
\hline Total & 21 & 9 & 31 \\
& 100.00 & 100.00 & 100.00 \\
\hline
\end{tabular}

Note: Pearson chi2 $(1)=2.8388 \quad \operatorname{Pr}=0.242$ 


\section{A. Supplemental Survey Results Regarding the Ombuds Process for Consumer Financial Dispute Resolution}

Supplementing the quantitative survey results, the open ended section of the survey identified a number of benefits associated with the ombuds process of consumer financial dispute resolution. Among the benefits include the fact that the process constitutes an 'impartial review service provided free of charge to financial customers'. In addition it helps to 'improve financial literacy of customer[s]' and 'helps to identify areas of improvement for bank[s].' ${ }^{99}$ In addition, it provides 'parities with a sense of self-determination' and a 'platform to be heard., 100 Avoidance of costly court proceedings was likewise cited as a benefit of the process. ${ }^{101}$ Finally the process is 'quick, free and confidential., 102

Perhaps as a result of such benefits, the use of ombuds processes has been increasing in recent years. In response to the question, 'do you see an increase in the use of ombuds services ...' the majority of respondents ( 89 per cent) indicated that they had in fact seen an increase in the use of ombuds processes in consumer financial dispute resolution in recent years.

In examining the results of the survey regarding the rate of settlement in a multi-tiered ombuds process, over 87 per cent of respondents observed that settlement occurred in 40-100 per cent of cases. This appears to be a positive rate of settlement and provides an indication of the overall effectiveness of the process.

\section{Areas for Improvement}

At the same time, those surveyed identified a number of areas in which the ombuds processes could be improved in resolving consumer financial disputes. These included 'increased public information including 'pamphlets, bank website and regulator websites' as 'many still don't know about [the] service.' 103 In addition,

\footnotetext{
${ }^{99}$ Survey No. 1 (July 2011-March 2012).

${ }^{100}$ Survey No. 2 (July 2011-March 2012).

${ }^{101}$ Survey No. 3 (July 2011-March 2012).

102 Survey No. 4 (July 2011-March 2012).

${ }^{103}$ Survey No. 1 (July 2011-March 2012).
} 
some have suggested the need to cultivate greater "business "buy-in" and cooperation., 104

While a number of areas exist for continued improvement in the delivery of consumer financial ombuds services, overall, the majority of respondents (62 per cent) noted general satisfaction on the part of users with the overall ombuds process.

\section{Suggestions for Further Development}

Finally, in response to the question, "what suggestions do you have for improving the overall process' of consumer financial dispute resolution, participants shared a number of helpful observations. These included, 'increased financial literacy of consumers on a whole', 105 "more "teeth" to the process, ${ }^{106}$ a system of oversight by which to "ensure awareness and quality of the interventions"107 and '[stat]utory requirements to [establish] an ADR system' in those jurisdictions that do not yet have such requirements. ${ }^{108}$

\section{Summary}

Overall, the findings of the survey indicate that practitioners of consumer financial dispute resolution view ombuds processes as particularly useful in providing an independent and free review service for financial customers. In particular, the ombuds service provides for checks on the system in the form of decisions rendered without prejudice to the claimant, thereby permitting the claimant to further pursue claims in court. At the same time the service also helps to identify areas of improvement and reform for banks. ${ }^{109}$ Perhaps as a result of such benefits, the use of ombuds processes has been increasing in recent years. The majority of respondents (89 per cent) indicated that they had in fact seen an increase in the use of ombuds processes in consumer financial dispute resolution in recent years. At the same time,

\footnotetext{
${ }^{104}$ Survey No. 3 (July 2011-March 2012).

${ }^{105}$ Survey No. 1 (July 2011-March 2012).

${ }^{106}$ Survey No. 3 (July 2011-March 2012).

${ }^{107}$ Survey No. 4 (July 2011-March 2012).

${ }^{108}$ Survey No. 5 (July 2011-March 2012).

${ }^{109}$ Survey No. 1 (July 2011-March 2012).
} 
practitioners acknowledged areas for continued improvement including the need for greater public education, ${ }^{110}$ oversight and quality assurance of ombuds processes. ${ }^{111}$

\section{B. Supplemental Survey Findings Regarding the Arbitration Process}

The summary of the findings in relation to the arbitration process are as follows: Arbitration practitioners viewed the benefits of arbitration services in consumer financial disputes as providing disputants with technical expertise "where the parties are not arguing over the law, but application of financial/accounting principles.' 112 In addition, respondents noted the 'speed, reduced expense and expertise of the neutral.' Among the challenges include 'proof issues, imbalance of power and information and lack of full discovery options/rights' ${ }^{113}$ Concerns about such disparities were echoed by other participants who noted the prevalence of perceptions that 'large institutions have "repeat-user" advantage'. ${ }^{114}$ Practitioners noted suggestions for improvement including the need for ' $[\mathrm{g}]$ ood program design [including] exit evaluations [and a] grievance process to allow parties to file complaints against neutrals who do not perform well'. In addition, 'a code of ethics for neutrals' was suggested along with 'anything that supports procedural due process'. 115

\section{Benefits of using an Arbitration Process for Consumer Financial Disputes}

Practitioners were asked about what they saw as the benefits of using arbitration to resolve consumer financial disputes. The responses ranged from, 'speed; reduced expense; expertise of the neutral ${ }^{116}$, to technical expertise, 'where the parties are not arguing over the law, but application of financial/accounting principles, it makes sense for the parties to hire a firm... to act as the "judge" (arbitrator) to settle the dispute'. ${ }^{117}$ This view is echoed by other survey respondents who observed that

\footnotetext{
${ }^{110}$ Survey No. 1 (July 2011-March 2012).

${ }^{111}$ Survey No. 4 (July 2011-March 2012).

${ }^{112}$ Survey No. 8 (July 2011-March 2012).

${ }^{113}$ Survey No. 10 (July 2011-March 2012).

${ }^{114}$ Survey No. 14 (July 2011-March 2012).

115 Survey No. 10 (July 2011-March 2012).

${ }^{116}$ Survey No. 7 (July 2011-March 2012).

117 Survey No. 8 (July 2011-March 2012).
} 
the process is 'more expeditious [because the] resolution [is performed] by neutrals who understand finance'. ${ }^{118}$ Others noted that the process is 'cost effective" ${ }^{, 19}$ in that it helps parties to 'avoid costly litigation, especially in light of the new United States Supreme Court decision governing class actions. [It] can offer procedural justice, if [a] program is properly designed. ${ }^{, 120}$ Finally, respondents noted that the process relies on 'established, court-tested Rules, and ... arbitrators with financial dispute experience'. ${ }^{121}$

In addition to the direct benefits of the arbitration processes, those involved in the delivery of a multi-tier process of arbitration preceded by mediation or negotiation noted a number of additional benefits. These include, 'cost-time saving[s]', ${ }^{122}$ 'bringing about resolution and peace to stakeholders in conflict', ${ }^{123}$ 'give[ing] parties [the] opportunity to avoid stress associated with [court] proceedings' ${ }^{124}$ 'provid[ing] a mechanism for dialogue ${ }^{, 125}$ and 'keeping friendships between main contractors and subcontractors looking forward to working together again on the next project'. ${ }^{126}$

In examining the results of the survey regarding the rate of settlement in a multi-tiered arbitration process, over 67 per cent of respondents observed that settlement occurred in 40-100 per cent of cases.

\section{Challenges in Implementing the use of Arbitration in Consumer Financial}

\section{Disputes}

Among the challenges practitioners observed in the use of arbitration to resolve consumer financial disputes include difficulties with 'administration. ${ }^{127}$ In addition, some have noted limitations in the extent to which 'bankers have incorporated ... arbitration clause[s] into their contracts. ${ }^{128}$ Others have noted that the process involves 'essentially tough distributive bargaining' and that often there are 'proof issues, imbalance of power and information, lack of full discovery

\footnotetext{
${ }^{118}$ Survey No. 13 (July 2011-March 2012).

${ }^{119}$ Survey No. 9 (July 2011-March 2012).

${ }^{120}$ Survey No. 10 (July 2011-March 2012).

${ }^{121}$ Survey No. 14 (July 2011-March 2012).

122 Survey Nos. 15, 21, 22, 24, 25 (July 2011-March 2012).

${ }^{123}$ Survey No. 18 (July 2011-March 2012).

${ }^{124}$ Survey No. 20 (July 2011-March 2012).

${ }^{125}$ Survey No. 23 (July 2011-March 2012).

${ }^{126}$ Survey No. 26 (July 2011-March 2012).

${ }^{127}$ Survey No. 7 (July 2011-March 2012).

${ }^{128}$ Survey No. 9 (July 2011-March 2012).
} 
options/rights'. ${ }^{129}$ Concerns about such disparities were echoed by other participants who noted the prevalence of perceptions that "large institutions have "repeat-user" advantage. ${ }^{130}$ In addition, some arbitrators noted that they faced difficulty in 'bring[ing] the parties together'. ${ }^{131}$ In addition, in some cases, there were challenges with '[i]mpleading ... other necessary parties who are not party to the arbitration agreement' alongside 'reluctance in judicial assistance' and at times 'unwarranted judicial intervention in the process'. ${ }^{132}$

In addition to the direct challenges associated with the arbitration processes, those involved in the delivery of a multi-tier process of arbitration preceded by mediation or negotiation noted a number of unique challenges. These include lack of 'knowledge of ADR [and] willingness to participate', ${ }^{133}$ including the need to educate 'people in conflict that there are cost effective and humane alternatives to litigation', 134 'difficulties in enforcing judgments ... (in some settings)', ${ }^{135}$ government cuts in funding ${ }^{136}$ and assisting parties to come to agreement ${ }^{137}$ particularly in the context of 'lawyers wanting to make fees by taking matters to full litigation'. 138

While a number of areas exist for continued improvement in the delivery of consumer financial arbitration services, overall, the large majority of practitioners (78 per cent) perceived that claimants were satisfied overall with the process.

\section{Suggestions for Improving Overall Efficacy of the Arbitration Process in Consumer Financial Disputes}

Arbitration practitioners were also asked about what suggestions they have for improving the overall efficacy of the process. Suggestions included the need for parties to include arbitration provisions in their contracts and the utility of hiring

\footnotetext{
${ }^{129}$ Survey No. 10 (July 2011-March 2012).

${ }^{130}$ Survey No. 14 (July 2011-March 2012).

${ }^{131}$ Survey No. 11 (July 2011-March 2012).

${ }^{132}$ Survey No. 13 (July 2011-March 2012).

${ }^{133}$ Survey Nos. 15, 23 (July 2011-March 2012).

${ }^{134}$ Survey No. 18 (July 2011-March 2012).

${ }^{135}$ Survey No. 16 (July 2011-March 2012).

${ }^{136}$ Survey Nos. 17, 21, 22 (July 2011-March 2012).

${ }^{137}$ Survey No. 19 (July 2011-March 2012).

${ }^{138}$ Survey No. 24 (July 2011-March 2012).
} 
subject-matter specialists including those with expertise in accounting. ${ }^{139}$ Further, 'parties should be more open to the mediation process to try and resolve some, if not all, items. ${ }^{140}$ In addition, improved training for neutrals was highlighted. One respondent noted the need for '[g] ood program design [including] exit evaluations [and a] grievance process to allow parties to file complaints against neutrals who do not perform well'. In addition, 'a code of ethics for neutrals' was suggested along with 'anything that supports procedural due process'. ${ }^{141}$ Along these lines, one participant noted the need for 'early and vigorous case- and discoverymanagement'. ${ }^{142}$ A number of individuals suggested more 'public information' about the arbitration process ${ }^{143}$ including "public educational campaign[s] about the process and better judicial cooperation in appropriate cases and non-intervention' ${ }^{144}$

In addition to the specific suggestions associated with the arbitration processes, those involved in the delivery of a multi-tier process of arbitration preceded by mediation or negotiation noted a number of specific suggestions for improving its overall efficacy. These included greater public "education" about the process' ${ }^{145}$, and 'effort to expedite the process and control costs ... [as] arbitration used to be an effective alternative to litigation but now it has also become very expensive'. ${ }^{146}$ In this light, some have suggested a 'move toward binding mediation'. ${ }^{147}$ Finally, a number of respondents suggested the need for greater 'training, workshops and meet-up[s] for neutrals' ${ }^{148}$

\footnotetext{
${ }^{139}$ See for example, Steven Brams, "Two-Person Cake-Cutting: The Optimal Number of Cuts" (with Julius B. Barbanel)

${ }^{140}$ Survey No. 8 (July 2011-March 2012).

${ }^{141}$ Survey No. 10 (July 2011-March 2012).

${ }^{142}$ Survey No. 14 (July 2011-March 2012).

${ }^{143}$ Survey No. 12 (July 2011-March 2012).

${ }^{144}$ Survey No. 13 (July 2011-March 2012).

${ }^{145}$ Survey Nos. 15, 19 (July 2011-March 2012).

${ }^{146}$ Survey No. 16 (July 2011-March 2012).

${ }^{147}$ Survey No. 16 (July 2011-March 2012).

${ }^{148}$ Survey No. 18 (July 2011-March 2012).
} 


\section{Conclusion}

Given the small size of the study ( $\mathrm{n}=49$ ), caution must be given to overgeneralization and extrapolating beyond the sample group. Further research will be required to extend these findings and offer more comprehensive conclusions. In the immediate term, however, consideration may be given to exploring possible applications of ombuds processes in the context of consumer financial dispute resolution in the United States.

Largely reflecting many of the benefits as well as some of the challenges facing consumer financial arbitration, the use of arbitration in resolving consumer financial disputes has expanded at a moderate rate. Recent legislation in the United States for example, has sought to limit the obligation to submit to some mandatory consumer credit card arbitration schemes. Overall, the benefits of ombuds process principally, the provision of an independent and free review service for financial customers, coupled with an internal check on the system in the form of decisions rendered without prejudice on the claimant, provide important safeguards against abuse. At the same time the service also helps to identify areas of improvement and reform for banks. ${ }^{149}$ Perhaps as a result of such benefits, the use of ombuds processes has been increasing in recent years. The majority of respondents indicated that they had in fact seen an increase in the use of ombuds processes in consumer financial dispute resolution in recent years. At the same time, practitioners acknowledged areas for continued improvement including the need for greater public education, ${ }^{150}$ oversight and quality assurance of ombuds processes. ${ }^{151}$

\footnotetext{
${ }^{149}$ Survey No. 1 (July 2011-March 2012).

${ }^{150}$ Survey No. 1 (July 2011-March 2012).

${ }^{151}$ Survey No. 4 (July 2011-March 2012).
} 